


\title{
Gaps and analogies in the formation of registered capital of limited liability and joint-stock companies
}

\author{
DOI: https://doi.org/10.46398/cuestpol.3969.14
}

Viktor Mikryukov *

\begin{abstract}
The aim of the research is to analyses and, using analogy, to examine exhaustively the areas of legal uncertainty in the mechanism of social capital formation of commercial entities, while at the same time checking the coherence of the statutory analogy and the analogy in law as a universal means of protecting and combating gaps in the business sphere. A combination of general logical methods of analysis and synthesis, induction and deduction, comparison and generalization, characteristic of works dealing with civil law, were applied. At the same time, the analogy method was used as a research tool and as a research tool. The conclusions of the work include the identification of specific gaps in the legal regulation of the procedure, methods, and terms of payment of share capital, the identification of ways to overcome these gaps casually and the formulation of proposals for the legislative updating of the regulatory structure of the
\end{abstract} share capital of commercial companies.

Keywords: analogy in law; gaps in legislation; joint-stock company; limited liability company; registered capital.

* Kutafin Moscow State Law University, 9 Sadovaya-Kudrinskaya St., Moscow, 125993, Russia. ORCID ID: https://orcid.org/oooo-00o2-6856-1627. Email: mikryukov.viktor@yandex.ru 


\footnotetext{
Viktor Mikryukov

238

Gaps and analogies in the formation of registered capital of limited liability and joint-stock companies
}

\section{Brechas y analogías en la formación de capital registrado de responsabilidad limitada y sociedades anónimas}

\section{Resumen}

El objetivo de la investigación es analizar y, utilizando la analogía, examinar exhaustivamente las áreas de incertidumbre jurídica en el mecanismo de formación del capital social de las entidades comerciales, al tiempo que se comprueba la coherencia dela analogía estatutaria y la analogía en el derecho como un medio universal de protección y lucha contra las lagunas en la esfera empresarial. Se aplicaron una combinación de métodos lógicos generales de análisis y síntesis, inducción y deducción, comparación y generalización, característicos de las obras que tratan del derecho civil. Al mismo tiempo, el método de la analogía se utilizó como instrumento de investigación y como objeto de investigación. Entre las conclusiones de la labor figuran la determinación de lagunas concretas en la reglamentación jurídica del procedimiento, los métodos y las condiciones de pago del capital social, la identificación de formas de superar casualmente esas lagunas y la formulación de propuestas para la actualización legislativa de la estructura reglamentaria del capital social de las sociedades comerciales.

Palabras clave: analogía en el derecho; lagunas en la legislación; sociedad anónima; sociedad de responsabilidad limitada; capital social.

\section{Introduction}

Establishing the need and the procedure for the formation of the registered capital when creating such business entities as a limited liability company (LLC) and a joint-stock company (JSC) is considered one of the bottlenecks of corporate law (Filippova, 2012). In the Russian and foreign doctrine, there are continued disputes about possible ways in civil law to protect the interests of investors and creditors which are associated with the use of the structure of a corporate legal entity (Galkova, 2015). Mechanisms are being discussed to upgrade the efficiency of investment schemes in corporate capital and to ensure corporate control adequate to the investments made (Hansmann and Kraakman, 2004). In most of the relevant discussions, the researchers focus on the structure of the registered capital anyway.

The lack of unity in the doctrinal assessments of this structure predetermines the imperfection of the current legislation in this area, which, in turn, entails a significant number of disputes related to the 
performance, non-performance, or improper performance of such a key corporate obligation as the payment of the registered capital of LLC and JSC. The aforesaid indicates the need for a particular study to establish and, using analogy, overcome, and then wholly eliminate gaps in the mechanism of formation of registered capital of business entities.

The research helps achieve greater corporate legal certainty and simultaneously contributes to the additional development of the analogy method potential in the legal regulation of economic activity.

\section{Literature Review}

The registered capital for such organizational and legal forms of commercial business corporations as LLC and JSC is rightly defined in the literature as a systemically important structure (Glushetskiy, 2020). The particular significance of the complete and consistent regulatory consolidation of this legal structure is not only that the legal concepts of LLC and JSC are based on such a key feature as the division of the registered capital into shares (Cl. 1, Art. 87 of the Civil Code of the Russian Federation) and a certain number of equities (Cl. 1, Article 96 of the Civil Code of the Russian Federation), but also in the fact that the registered capital of these business entities provides a broad functionality (guarantees the interests of creditors (Povarov, 2010), ensures the formation and replenishment of the property base of the organization (Rubeko, 2016), identifies the size of participation in profits and losses (Dolinskaya, 2006), determines the volume of corporate and managerial capabilities of participants, indicates the degree of deepness of the corporation's commercial aspirations (Sukhanov, 2012), and therefore is reflected in almost all spheres of life of LLC and JSC.

Since LLC and JSC, created mainly as capital pooling, as business partnerships (Filippova, 2018), the key function (not highlighted and even ignored by the legislator (Sayapina, 2005), but at the same time actually working) is the property (starting, material and securing) function of the registered capital, and the property itself, transferred by the founders (participants) as contributions (installments) to the registered capital, occupies a special place in the system of legal entity's property relations (Dolinskaya, 2017) and becomes an element of corporate property (Laptev, 2017), in so far the detailed and gapless regulation of the procedure for the formation of the registered capital of LLC and JSC is seen as fundamental (as it is correctly highlighted in science, a vague law in most cases does not cope well with the task of guiding human behavior (Asgeirsson, 2015). Indeed, the further functioning of the company largely depends on the degree of effectiveness of actions carried out when paying in the registered 
capital (Tarasenko, 2005).

However, it can be said that today there are some areas of regulatory uncertainty, generally considered in the doctrine as a negative factor, a defect of the legal system that undermines the ability of the law to achieve the necessary results (Davis, 2011) and complicates the private legal process of actual paying in the registered capital of LLC and JSC. In particular, the literature draws attention to the ambiguity of the legal nature (personal or impersonal) of the participants' (shareholders') obligation to pay the corporation's registered capital (Kozlova and Filippova, 2012), the uncertainty of the consequences of failure to perform or delay this obligation fulfillment (Dmitrieva, 2013). Based on these observations, it seems necessary to analyze the existing regulatory parameters of the mechanism more thoroughly and comprehensively for the formation of the LLC and JSC registered capital to identify and legalize legal gaps.

When faced with gaps, the question inevitably arises about the possibility and necessity of resorting to the statutory analogy (the application of legal norms to situations that do not directly fall under the classification of this norm) (Macagno and Walton, 2009) or to the analogy in law (the identification of the rights and obligations of the parties of the disputed relationship is not according to specific norms, but according to the socalled "general legal principles") (Damele, 2014). Therefore, using the example of how the analogy method manifests itself when it is used in the gap elements of the mechanism for forming the LLC and JSC registered capital, it seems necessary to check (confirm or clarify) the idea of the "central role" of analogy in any legal reasoning (Hunter, 2008), as well as theses expressed in science about the relevance and effectiveness of legal analogy as a "bridge between fact and rule" (Weinreb, 2005), a convenient mechanism for prompt overcoming regulatory gaps in law enforcement practice (Petrovsky, 2009), the usual means of legal argumentation and explanation of legal phenomena (Juthe, 2005).

\section{Materials and Methods}

The theoretical basis for the undertaken research was formed by scientific works of Russian and foreign civil scientists, specialists in corporate law and economic analysis of law.

The empirical material used was based on clarifying judicial acts of the supreme courts in Russia, as well as a significant number of decisions of lower courts on specific disputes related to the application of the rules on the procedure for forming the registered capital of business entities (LLC and JSC). 
The methodological base of this work includes the logical methods of analysis and synthesis, induction and deduction, comparison and generalization, typology, and analogy, traditional for civil studies. A special place in the system of methods applied was performed by analogy, which was both a means and an object of study.

\section{Results}

As a result of the study, real gaps in the legal regulation of the procedure, methods, and timing forming the registered capital of business entities (LLC and JSC) have been found and legally qualified. The cited real practical incidents made it possible to visually illustrate and additionally confirm the "live" nature of analogy as an element of modern corporate legal technology, an actual means of exercising and protecting corporate rights, the stage of application of law and a factor in the legislation development.

It is argued that in a state of such legal uncertainty, when, from a formal point of view, there is no gap in the law, but the existing norms are not able to adequately respond to specific socio-economic realities and ensure the implementation of the key principles of corporate law, the most effective instrument of law enforcement is the analogy in law (Cl. 6 of the Civil Code of the Russian Federation), applying which the direct participants in the relevant corporate relations bring their behavior under the direct influence of the basic principles of civil legislation, and the courts receive an effective legal means of balancing the private interests of the corporation, its participants and counterparties.

Bearing in mind that the exact rules still more consistently regulate ordinary phenomena (to which all the issues discussed above can be attributed) than general principles (Braithwaite, 2002), and also considering that the mechanism of applying the analogy in law, although aims to achieve absolute legal certainty (and ensures its achievement) is itself associated with the chicanery-intensive discretion both on the part of the participants in the relevant legal relations and on the part of law officials, it is proposed to eliminate the detected gaps in a regulatory way.

\section{Discussion}

\subsection{Paying in a contribution to the registered capital by a third party}

There is no direct legislative decision and an unambiguous doctrinal answer to the question of whether it is permissible to make contributions 
to the payment of the registered capital of a company not by a participant (shareholder) personally, but by a third party (by the legal entity, another participant or generally an outside entity that is not part of the corporate network of the organization) and, accordingly, should the formation of the registered capital be considered valid, and the participant (shareholder) having fulfilled one of the key (essential) duties to the corporation in case of the actual implementation of such payment.

On the one hand, the approach has gained considerable popularity in judicial practice, according to which the obligation of a participant (shareholder) to pay in a share in the registered capital of LLC (issued shares when establishing a JSC) can be performed for him by other persons. Thus, the courts specify that the Federal Law of February 8, 1998 No. 14FZ "On Limited Liability Companies" (Federal Law "On LLC") does not require the obligation to pay in the registered capital of the company by its participants, depending on whether the participant personally paid in his share or payment was made by other persons for him (Resolution of the Arbitration Court of the East Siberian District of February 14, 2019, Case No. A78-17696/2017). The current legislation does not provide for a prohibition on making a contribution to the registered capital of a legal entity for a particular founder by another member of this organization or a third party (Resolution of the Arbitration Court of the Far Eastern Federal District of March 15, 2017, Case No. A59-1172/2016).

In the courts' opinion, the fact of the full formation of the corporation's registered capital or the payment of the share of the relevant person (participant, shareholder) is of legal significance, and in assessing this circumstance, the way (at whose expense), the registered capital was provided, or the share of the person concerned was paid in, does not play an independent legal role (Resolution of the Arbitration Court of the Volga District of May 20, 2020, Case No. A12-26686/2019). Concerning JSC, the courts proceed from the assumption that when finding the fact of full payment for all shares placed while establishing the organization, the shares that could pass to the company according to para. 4, Cl. 1, Art. 34 of the Federal Law of December 26, 1995, No. 208-FZ "On Joint-Stock Companies" (Federal Law "On JSC") are missing, therefore there are no grounds for depriving a shareholder who has personally failed to fulfill the relevant duty of the right to participate in the meeting and vote on agenda items (Resolution of the Federal Arbitration Court of the East Siberian District of July 15, 2008, Case No. A19-4509/05-53-6-4).

According to courts, it is also possible that the issuer himself will pay for the placed shares using borrowed funds (Resolution of the Federal Arbitration Court of the North Caucasian District of January 27, 2009, Case No. A32-11917/2007-55/274-2008-16/37). In science, the regulatory basis for this judicial position is seen in applying the provisions of Art. 313 of the 
Civil Code of the Russian Federation established under a statutory analogy from para. 1, Art. 6 of the Civil Code of the Russian Federation (Dmitrieva, 2013).

Special instruction in Cl. 1 of Art. 15 of the Federal Law "On LLC" on the obligation of "each founder" of the LLC to pay in full its share in the company's registered capital, as well as the standard rules in Cl. 2 of Art. 90 and Cl. 2 of Art. 99 of the Civil Code of the Russian Federation on the inadmissibility of releasing an LLC participant (JSC shareholder) from the obligation to pay for a share in the registered capital (shares) of a company, lead to the conclusion that the obligation to pay the registered capital is strictly of personal nature, which excludes the possibility of imposing the performance of the duty on a third party according to Art. 313 of the Civil Code of the Russian Federation (Kozlova and Filippova, 2012). Relying on this conclusion, some courts consider the terms of the Agreement for the Establishment of an LLC on payment of a share in the registered capital of the company by one participant for another to be contrary to the law requirements (Resolution of the Federal Arbitration Court of the Central District of April 21, 2009, Case No. A54-1591/2008C9) and deny that the participant has the full scope of corporate rights if, although the information on the completion of the registered capital establishment is reflected in the corporation's balance sheet, there is an unresolved conflict about who exactly paid in this participant's contribution (Resolution of the Federal Arbitration Court of the West Siberian District of June 19, 2008, Case No. A03-3150/07-37).

Besides, while solving the issue mentioned above, the provisions of Art. 313 of the Civil Code of the Russian Federation on the conditions and consequences of the fulfillment of an obligation by a third party (including those obliging the creditor to accept the performance offered by a third party for the debtor, even if the debtor did not impose the fulfillment of the overdue obligation on the latter) are applied, it is possible to see a contradiction to the peremptory norms (para. 3, Art. 16 of the Federal Law on LLC and para. 4 Cl. 1 of Art. 34 of the Federal Law "On JSC"), establishing a notable consequence of non-payment of shares (stocks) upon the organization of LLC and JSC - such (unpaid) shares (stocks) upon the expiry of the established period for their payment are transferred to the company (the basis for the transition is the very fact of expiration of the period for payment (Resolution of the Arbitration Court of the Volga District of March 6, 2017, Case No. A06-4712/2016).

This particular consequence is perceived in court practice in such a way that a corporation has no right to compel its participants (shareholders) to fulfill the obligation to pay for shares (stocks) in kind (Definition of the Supreme Arbitration Court of the Russian Federation of January 16, 2014, Case No. A76-8250/2009-64-159; Definition of the Supreme Arbitration 
Gaps and analogies in the formation of registered capital of limited liability and joint-stock companies

Court of the Russian Federation of April 19, 2011, Case No. A46-2352/2010; Resolution of the Arbitration Court of the Far Eastern District of February 15, 2017, Case No. A04-3521/2016). Insofar as the participant (shareholder) avoids this obligation, it is regarded as a refusal of corporate participation. Its implementation by a third party or the corporation, which is not agreed with it, violates the principle of exclusively voluntary involvement of investors in the formation of the registered capital of companies, recognized in science and constitutional practice (Kuznetsov, 2011).

It appears that if we resort to the clarification of the proper legislative intentions that predetermined the adoption of this or that regulation, which is recognized as necessary for any law enforcer (Kyritsis, 2018), then it should be concluded that the legislator's intention to demand personal fulfillment of the obligation to make contributions to the registered capital does not arise. Such a requirement does not appear due to the essence of the non-personal property obligation under consideration. Simultaneously, the highlighted normative reference to the responsibility of "each" founder to pay their share can be characterized as one of the many terminological errors that, for some excused reasons, accompany any legislative area (Golubtsov, 2018). Therefore, taking into account the idea that both the participants (shareholders) and the corporation have the obligation to form the registered capital, since the registered capital is included in the organization's property characteristic (Dolinskaya and Kuznetsov, 2012), it is hardly correct to limit the imposing this obligation on third parties at the debtor's initiative. On this basis, the judicial practice confirming this possibility should be supported.

Another matter is that the aforementioned doctrinal doubts about the impersonal nature of the obligation to replenish the registered capital, the encountered judicial acts with the contrary position, and fears that the broad and unconditional application of the provisions of Art. 313 of the Civil Code of the Russian Federation for payment of contributions to the registered capital for participants (shareholders) by third parties may lead to bypassing the mandatory norms of $\mathrm{Cl}$. 3 of Art. 16 of the Federal Law "On LLC" and par. 4, Cl. 1 of Art. 34 Federal Law "On JSC" and compulsory corporate investment. Taking into consideration that legal certainty, which is a hallmark of the rule of law, plays a fundamental role in law due to its economic optimality for market participants (Portuese et al., 2013), it seems appropriate to fill the existing legal gap in a regulatory way and make legislative adjustments in para. 2 of Art. 90 and in para. 2 of Art. 99 of the Civil Code of the Russian Federation, namely: firstly, to establish that the participant's obligation to pay for its share in the registered capital of LLC (the duty of a shareholder to pay for the shares placed by the JSC and acquired by the shareholder) may be imposed by the participant (shareholder) on the organization, other participants (shareholders) of this company or other third party; secondly, to clarify that LLC and JSC are not entitled to 
fulfill the corresponding obligation for the participant (shareholder) if the participant (shareholder) did not entrust the performance to the company; thirdly, the company is not entitled to accept the performance offered for the participant (shareholder) by other participants (shareholders) of this company or other third parties, if the participant (shareholder) did not entrust the performance to the persons concerned.

\subsection{Late payment of contributions to the registered capital}

Another gap in the legal regulation of the procedure for the formation of the registered capital of business entities (LLC and JSC) is that the consequences of violation of the term for payment by participants (shareholders) of shares (stocks) established by the Agreement for the Establishment of the Company following the limit regulatory values are not clearly and completely determined (para. 1, Cl. 1 of Article 16 of the Federal Law "On LLC", para. 1.2, Cl. 1 of Article 34 of the Federal Law "On JSC").

On the one hand, based on a literal reading of the provisions of para. 3 of Art. 16 of the Federal Law "On LLC" and para. 4, Cl. 1 of Art. 34 of the Federal Law "On LLC", in the event of non-payment or incomplete payment of the share (stocks) within the time limits established in accordance with the law, the unpaid part of the share (stocks, the placement price of which corresponds to the unpaid amount) is transferred to the company. Such a transfer and, accordingly, the loss of the status of a participant (shareholder) by the violator of the obligation to replenish the registered capital of the corporation occurs automatically. Sharing this letter of the law interpretation, scientists emphasize the automatism of the transition of unpaid shares (stocks) (Dmitrieva, 2013) and focus on the preclusive nature of the term for payment of contributions to the registered capital (Klinova, 2007).

The courts, when establishing the expiration of such a period, deny the corporate possibility of a faulty (not making a timely contribution to the registered capital) participant (shareholder) to participate in decisionmaking at general meetings (Resolution of the Federal Arbitration Court of the Central District of July 14, 2008, Case No. A68-5851/07-168/16) and challenge the decisions of the company's bodies (Definition of the Supreme Arbitration Court of the Russian Federation of December 09, 2009, Case No. A07-20700/2008). Besides, the Constitutional Court of the Russian Federation did not find a contradiction with the Constitution of the Russian Federation in the fact that these provisions do not require additional expressions of the will of the faulty participant to transfer unpaid shares (stocks) to the company (Definition of the Constitutional Court of the Russian Federation dated October 25, 2018, No. 2615-O). 
Therefore, it is generally accepted in notarial practice that if at the time of the opening of the inheritance, the share in the registered capital of the LLC was not paid in full by the testator, and the deadline for full payment has not expired, the inheritance will include the total share in the registered capital of the company that belonged to the testator at the time of his death, while the obligation to pay the share in full passes to the heirs, and if the period established for the full payment of the share by the time of opening the inheritance has expired, only the paid part of the share in the registered capital is included in the mass of the succession, and the amount of the share not paid by the testator passes to the corporation (Cl. 2.5. Methodological recommendations on Inheritance of Shares in the Registered Capital of Limited Liability Companies (approved at a meeting of the Coordination and Methodological Council of notarial chambers of the Southern Federal District, North Caucasian Federal District, Central Federal District of the Russian Federation 28-29.05.2010).

Besides, it is the idea of automating the transfer of unpaid shares (stocks) that forms the basis for the conclusion worded by the courts (para.10 of the Information Letter of the Presidium of the Supreme Arbitration Court of the Russian Federation dated May 24, 2012 No. 151 Review of the Practice of Consideration by Arbitration Courts of Disputes Related to the Exclusion of a Participant from a Limited Liability Company) and approved in science (Gutnikov, 2015), that it is inadmissible to exclude a participant from the corporation membership for violation of the obligation to contribute to the registered capital.

In other words, there are reasonable grounds to believe that participants (shareholders) or their successors, in the event of a delay in fulfilling the obligation to pay shares in the registered capital of LLC (shares placed by JSC), are automatically deprived of corporate ties with the company. The payment made beyond the established period is an unjust enrichment of the company and must be returned. In practice, there are examples of assessing the overdue payment of a contribution to the registered capital as improper, having no corporate significance (Resolution of the Federal Arbitration Court of the Volga-Vyatka Region of February 19, 2008, Case No. A39-245/2007-9/14).

On the other hand, in some cases, the courts emphasize that only unpaid shares can be transferred to JSC (Resolution of the Federal Arbitration Court of the Ural District of July 21, 2009, Case No. A50-14459/2008-G14), and indicate (apparently, having in mind the analogy with the regulation of Art. 29 FZ of April 22, 1996 No. 39-FZ “On the Securities Market”), that until the unpaid shares are written off from the faulty owner's account and, accordingly, until they are returned to the issuer's account, formally being a shareholder, the person continues to have the corporate status of the company's shareholder (Resolution of the Federal Arbitration Court of the 
North Caucasian District of January 27, 2009, Case No. A32-11917/200755/274-2008-16/37). Based on these judgments, the courts reject attempts to consider the payment for the placed shares, carried out beyond the established deadlines, being invalid (Resolution of the Arbitration Court of the Volga District of September 01, 2016, Case No. A57-27205/2015).

Concerning cases of late payment of a share in the LLC registered capital and interpreting the rules of $\mathrm{Cl} .3$ of Art. 16 of the Federal Law "On LLC," the courts come to the same conclusion that if the LLC is running smoothly and have not disposed of the share unpaid by the participant within the timeframe established by Art. 24 of the Federal Law "On LLC," implicative actions of the violator (participation in corporate governance), other participants (long-term non-contestation of the violator's right to the unpaid share) and the company (interaction with the violator as a proper participant in the company) may be the basis for recognizing the status of a corporation participant for the person who did not pay the share (Resolution of the Presidium of the Supreme Arbitration Court of the Russian Federation of February 26, 2013, Case No. A42-6169/2011; Resolution of the Arbitration Court of the Volga-Vyatka Region of March 17, 2016, Case No. A29-4606/2015; Resolution of the Arbitration Court of the Volga District of December 10, 2019, Case No. A57-12783/2018).

There is an analogy here with the regular practice of recognizing a person who, having retained the complex of corporate rights and obligations of an LLC participant, applied to leave the company, but having not received from the company the actual value of his share in the registered capital, continues to participate in the company's corporate life (vote at general meetings of the company and receive dividends). The company does not undertake the actions provided for in para. 2, Art. 24 of the Federal Law "On LLC" to determine the fate of the share of the participant withdrawn (Resolution of the Arbitration Court of the Volga-Vyatka District of December 30, 2014, Case No. A43-2058/2011; Resolution of the Arbitration Court of the NorthWestern District of July 4, 2017, Case No. A56 -39738/2015; Resolution of the Federal Arbitration Court of the Volga District of August 16, 2010, Case No. A57-22863/2009).

Since the severance of the corporate relationship of a participant (shareholder) with LLC and JSC is always a particularly significant event, so goodwill aimed at maintaining such a relationship (if there is a technical (formal) possibility of its implementation and the absence of obvious contraindications) should have regulatory grounds.

Thus, taking into account the need to improve corporate legislation to achieve a reasonable balance of interests of a particular (obliged and having an overdue payment of the contribution) participant (shareholder) with the interests of other shareholders, the corporation, and its counterparties, it should be statutorily determined that payment of a share in the registered 
Viktor Mikryukov

Gaps and analogies in the formation of registered capital of limited liability and joint-stock companies

capital of LLC (payment for the shares placed by JSC) received by the company in violation of the established period, excludes the transfer of the share (stocks) to the company, and unless and until the corresponding payment was received by the company before the company applies to the registering authority (presentation of the transfer order to the registrar) about the transfer of the share (stocks) to the company, and if this condition is not met (with an even more significant delay), such payment is subject to refund as unjust enrichment.

\subsection{Payment of the contribution to the registered capital by offsetting the founder's counterclaims}

Another gap in the mechanism for the formation of the registered capital of business entities (LLC and JSC) appears in the lack of absolute clarity as to the possibility or inadmissibility of fulfilling the obligation of a participant (shareholder) to contribute to the registered capital by offsetting counterclaims against the company.

On the one hand, the abolition of the general prohibition on exemption of a limited liability company participant from the obligation to make a contribution to the registered capital by offsetting claims against the company (as it was established in Cl. 2 of Article 90 of the Civil Code of the Russian Federation as amended by the Federal Law of December 27, 2009 No. 352-FZ), exclusion of a similar prohibition on exemption of a shareholder from the obligation to pay for the company's shares by offsetting claims against the company (as it was worded in Cl. 2 of Art. 99 of the Civil Code of the Russian Federation as amended before the adoption of Federal Law of December 27, 2009 No. 352-FZ) and the simultaneous introduction of highly specialized clauses that in the cases provided for by the Federal Law "On LLC" and the Federal Law "On JSC," such offsets are possible with an increase in the registered capital of LLC and when paying for the JSC additional shares placed, can be regarded as a point approval of offsets, namely (only) in order to form a further part of the already created registered capital with its increase (Dolinskaya, 2010).

On the other hand, considering the admissibility of payment of the registered capital of a legal entity by promissory notes of its participants (Definition of the Supreme Arbitration Court of the Russian Federation of January 18, 2011, Case No. A56-59613/2009; Letter of the Ministry of Economic Development of Russia of December 29, 2018, No. OG-D2212808), it becomes clear that the idea of preventing the formation of registered capital bubbles and guaranteeing the interest of the company's creditors in replenishing the registered capital with real property, and not "ephemeral rights of claims of participants" (Boyko, 2010), by prohibiting the offset of claims during the initial formation of the registered capital, obviously doesn't work. 
It seems that fears of abuse, when individual participants, having the opportunity to influence the company's activities, begin to unfairly build up the company's debts to themselves to subsequently pay off the obligation by offsetting the registered capital payment, should not lead to a literal and rigid understanding of the prohibition under consideration (para. 2, Cl. 90, Art. 99 of the Civil Code of the Russian Federation) and prevent the provision of a convenient way for JSC and their participants to convert debts into corporate capital, because it is known that abusus non tollit usum (misuse of something is no argument against its proper use).

Given a legally permitted long period of existence of companies with an incompletely paid registered capital, a real (not bubble) debt of the company to a participant, whose share in the registered capital has not yet been paid, may arise, and, accordingly, a reasonable interest of the organization in good faith termination of counterclaims by offset, relieving both the corporation and its participant from the need to seek for current financial resources, may appear. It seems that corporate law, having as one of its most important tasks the promotion of the organization of investment in corporate capital and the provision of corporate control associated with the investment (Hansmann and Kraakman, 2004), should ensure the proper achievement of this interest. Accordingly, excessive rigidity of the rules on registered (authorized) capital increases transaction costs and hinders investment (Wei, 2014).

Therefore, taking into account the generally apparent negative effect of the lack of flexibility in the rule on the inadmissibility of payment of the registered capital by offsetting claims against the company (Telyukina, 2001), and considering that, strictly speaking, the termination of an obligation by offset is by no means debt forgiveness (as it is formulated in Art. 415 of the Civil Code of the Russian Federation) and the release of the debtor from the fulfillment of this obligation, it is advisable to move more actively towards further liberalization of the considered section of corporate legal regulation, excluding the general implied prohibition on payment of the registered capital of LLC and JSC (at its initial formation) by offsetting the founder's counterclaims (of course, subject to the rule of Cl. 2 of Art. 66.2 of the Civil Code of the Russian Federation on the required payment of the registered capital of LLC and JSC "alive" funds in an amount not lower than the minimum amount of the registered capital determined by special laws).

Significantly, that the corresponding change will be in line with the general trend noted in science and regularities in other jurisdictions (transition from a strict legal regime of capital to a more liberal and flexible control of registered capital) (Chen, 2015). Moreover, even before the relevant legislative amendments are made, it seems possible, without fear of reproaches in veiled imperfect judicial lawmaking (Schauer and Spellman, 
2017), using the analogy in law (Cl. 2, Art. 6 of the Civil Code of the Russian Federation) "extra legem" (placed outside the law), but "intra ius" (within the law) to recognize the payment of the LLC and JSC registered capital under formation as valid through an offset, carried out reasonably and in good faith, taking into account the actual balanced interests of the business corporation and its participants (shareholders).

\subsection{Payment of a contribution to the registered capital by the right relating to leasing property}

Surprisingly, the current legislation does not answer unambiguously to the question that is very relevant for many commercial business corporations and their founders (shareholders): is it possible to pay the registered capital of LLC and JSC by making (assigning) to the company the right to lease any property? The increasing demand for a lease agreement in the economic turnover, due to the widely observed trend towards the recognition of the advantages of the "sharing economy" concept and the corresponding benefits from the temporary use of necessary facilities instead of acquiring things for individual ownership (Botsman and Rogers, 2010) makes this particular issue even more relevant.

Following the current edition of $\mathrm{Cl} .1$ of Art. 15 of the Federal Law "On LLC," payment of shares in the LLC registered capital may be carried out by participants in money, securities, other things or property rights or other rights that have a monetary value. Similar wording is enshrined in the current version of Cl. 2 of Art. 34 of the Federal Law "On JSC," according to which payment for shares distributed among the founders of a JSC upon its establishment, as well as pay for additional shares placed by subscription, can be carried out in money, securities, other things or property rights or other rights that have a monetary value. A similar wording is enshrined in the current version of Cl. 2 of Art. 34 of the Federal Law "On JSC", according to which payment for shares distributed among the founders of JSC upon its establishment, as well as payment for additional shares placed by subscription, can be carried out in money, securities, other things, or property rights or other rights that have a monetary value. These provisions allow us to conclude that there are no corporate legal obstacles to transfer ring rental ownership to the LLC and JSC registered capital. Currently, there is the norm of para. 2 of Art. 615 of the Civil Code of the Russian Federation on the existing right of the lessee (by default in the law otherwise), with the consent of the lessor, to give lease rights as a pledge and make them as a contribution to the registered capital of business partnerships, LLC and JSC, which confirms the legality of the considered method of payment for the contribution to the registered capital according to the civil-law nature of the lease. 
At the same time, the emergence of the norm of para. 1 of Art. 66.1 of the Civil Code of the Russian Federation, introduced by the Federal Law of May 05, 2014 No. 99-FZ, subject to its priority until the legislative and other regulatory legal acts being in force in the Russian Federation under the provisions of the Civil Code of the Russian Federation as amended by this law, gave rise to serious doubts about the consistency of an affirmative answer to the question of the possibility of paying for the registered capital of a business corporation with the right to lease.

Since the specified norm established an exhaustive list of objects that can be invested in the LLC and JSC property (including, in addition to cash, things, shares (stocks) in the registered (joint) capitals of other business partnerships, LLC and JSC, state and municipal bonds, some exclusive intellectual rights and rights under license agreements subject to monetary assessment, though other property rights (claims) that could be of economic value were not included), insofar as the apprehension of contributions to the registered capital as a type of contributions to property (Melnikova, 2016) and recognition of the inadmissibility of expanding this list by laws and constituent documents in relation to the registered capital led to the denial of the possibility of making objects not named in the list as contributions to the registered capital, including the right to lease (Lomakin, 2020). Herewith, the general doctrinal criticism of allowing the functioning of legal entities that did not receive real money or corporeal objects of ownership (things) as payment for their registered capital (Emelkina, 2017) may further increase the corresponding doubts.

In this issue, based on a formal factor (after the adoption of the Federal Law of May 5, 2014 No. 99-FZ, both the Federal Law "On LLC" and the Federal Law "On JSC" that were repeatedly amended, which makes it possible to consider these laws under the Civil Code of the Russian Federation), it should be agreed that Art. 66.1 of the Civil Code of the Russian Federation works only in relation to business partnerships, as well as concerning operations for making contributions to the property of business companies that do not increase their registered capital (Kurbatov, 2018). At the same time, realizing the insufficiently robust nature of the formal argument (preservation of the wording of Cl. 1 of Article 15 of the Federal Law "On LLC" and Cl. 2 of Art. 34 of the Federal Law "On JSC" can equally be perceived that in terms of regulating the procedure for paying capital, these laws have not yet been cited following the Civil Code of the Russian Federation), it seems necessary to add that there is nothing a priori ephemeral in providing the opportunity to use leased property by the founder of the company (for example, a land plot for the construction of real estate or an office for representational purposes).

Therefore, in the context of continuing legal uncertainty, it is necessary to apply the general principles and meaning of civil legislation (analogy in 


\footnotetext{
Viktor Mikryukov 252

Gaps and analogies in the formation of registered capital of limited liability and joint-stock
companies
}

law) and, taking into account the requirements of good faith, reasonableness and fairness, support the approach implemented by some courts, according to which the payment of contributions to the registered capital of business companies (LLC and JSC) with rental rights is also permissible (Resolution of the Arbitration Court of the Ural District of May 29, 2019, Case No. A6039078/2018; Resolution of the Arbitration Court of the North-Western District of August 8, 2018, Case No. A66-10750/2015).

This application of the analogy in law will correspond to the currently observed general increase in the importance of civil law principles in the regulation of public relations (Golubtsov, 2016) and act as an adequate response to the rightful appeals of scientists for their even more enormous impact on the law enforcement practice (Bondarenko, 2013). Thus, based on analogy, recognition of the admissibility of payment of the LLC and JSC registered capital by the right to lease allows us to think of an even more excellent (double) analogy, namely, the possibility of converting into corporate capital the rights to use "unnamed things" belonging to a participant (shareholder) (Suslova, 2020) and other "atypical rental objects" (Mikryukov, 2020), when directly (and not by analogy) applying rental rules to them may be questionable.

\section{Conclusion}

The study reveals a lot of gaps in the legal mechanism for the formation of the LLC and JSC registered capital both in general issues of methods and terms of payment, and in particular cases of determining the list of objects that are allowed to be contributed to the registered capital, which requires vigorous and scientifically substantiated legislative decisions.

Since the participants of the respective legal relations and law enforcement officers achieve legal certainty using an analogy in each of the obscure areas under study in the system of rules for the formation of the LLC and JSC registered capital, the need for a generally positive assessment of the role of statutory analogy and analogy in law in the legal regulation of economic activity has been again confirmed.

The importance of the statutory analogy and the analogy in law is highlighted in the context of the implementation of the harmonizing function of civil law regulation of public relations, developing, specifically, in the corporate sphere. 


\section{Bibliographic References}

ASGEIRSSON, Hrafn. 2015. "On the instrumental value of vagueness in the law” In: Ethics. Vol. 125, No. 2, pp. 425-448. Available online. In: https:// papers.ssrn.com/sol3/papers.cfm?abstract_id=2506722. Consultation date: $11 / 11 / 2020$.

BONDARENKO, Natalia. 2013. "Modern methodological approach to the civil law principles research" In: Perm University Herald. Juridical Sciences. No. 4(22), pp. 305-309.

BOTSMAN, Rachel; ROGERS, Roo. 2010. What's Mine Is Yours: The Rise of Collaborative Consumption. Harper Business. New York, USA.

BOYKO, Tatiana. 2010. "A new stage in the liberalization of Russian corporate law: Federal Law No. 352-FZ” In: Corporate Lawyer. No. 3, pp. 17-20.

BRAITHWAITE, John. 2002. "Rules and principles: A theory of legal certainty" In: Australian Journal of Legal Philosophy. No. 27, pp. 47-82. Available online. In: https://papers.ssrn.com/sol3/papers.cfm?abstract_ $\mathrm{id}=329400$. Consultation date: $11 / 11 / 2020$.

CHEN, Ruoying. 2015. "From Legal Capital to Subscribed Capital: Capital Rules in China and its Economic Background" In: FLEISCHER, Holger; KANDA, Hideki; KIM, Kon S; MÜLBERT, Peter. (eds.) German and Asian Perspectives on Company Law. Mohr Siebeck. Tübingen, Germany. pp. 181-202.

DAMELE, Giovanni. 2014. "Analogia Legis and Analogia Iuris: An Overview from a Rhetorical Perspective” In: RIBEIRO, Henrique J. (ed.) Systematic Approaches to Argument by Analogy. Argumentation Library. Vol. 25. Springer. Cham, Switzerland. pp. 243-256. Available online. In: https:// link.springer.com/chapter/10.1007/978-3-319-06334-8_14\#citeas. Consultation date: 11/11/2020.

DAVIS, Kevin E. 2011. “The Concept of Legal Uncertainty" In: SSRN Electronic Journal. Available online. In: https://papers.ssrn.com/sol3/papers. cfm?abstract_id=1990813. Consultation date: 11/11/2020.

DMITRIEVA, Lilia. 2013. "On the issue of automatism of the transfer of a share in the registered capital (stocks) in case of non-fulfillment of obligations by a business entity participant" In: Law and Economics. No. 8, pp. 3439 .

DOLINSKAYA, Vladimira V. 2006. "The registered capital of a joint-stock company in the system of property relations" In: Lawyer. No. 7, pp. 49-51. 
Viktor Mikryukov

254

Gaps and analogies in the formation of registered capital of limited liability and joint-stock companies

DOLINSKAYA, Vladimira V. 2010. "Changes in civil and corporate law" In: Civilist. No. 2, pp. 23-29.

DOLINSKAYA, Vladimira V. 2017. "Property transferred as contributions (installments) to the registered (joint-stock, share) capital, in the system of property relations of a legal entity" In: Laws of Russia: Experience, Analysis, Practice. No. 2, pp. 22-28.

DOLINSKAYA, Vladimira V; KUZNETSOV, Viktor V. 2012. "Formation of registered capital and dividends" In: Laws of Russia: Experience, Analysis, Practice. No. 7, pp. 3-5.

EMELKINA, Irina. 2017. "Legal entities as subjects of property rights and limited property rights" In: Laws of Russia: Experience, Analysis, Practice. No. 2, pp. 3-9.

FEDERAL LAW NO. 14-FZ “ON LIMITED LIABILITY COMPANIES”. 1998. Available online. In: https://www.wto.org/english/thewto_e/acc_e/ rus_e/WTACCRUS58_LEG_371.pdf. Consultation date: 12/08/2020.

FEDERALLAWNO.208-FZ“ONJOINT-STOCKCOMPANIES”.1995.Available online. In: https://cbr.ru/Content/Document/File/33657/208-FZ.pdf. Consultation date: 12/08/2020.

FEDERAL LAW NO. 352-FZ "ON AMENDMENTS TO CERTAIN LEGISLATIVE ACTS OF THE RUSSIAN FEDERATION IN RESPECT OF AMENDMENTS TO CERTAIN LEGISLATIVE ACTS OF THE RUSSIAN FEDERATION IN RESPECT OF RESTRICTIONS FOR BUSINESS ENTITIES WHEN FORMING SHARE CAPITAL, REVISION OF METHODS OF PROTECTION OF CREDITORS' RIGHTS WHEN REDUCING SHARE CAPITAL, CHANGES IN REQUIREMENTS FOR BUSINESS ENTITIES WHEN SHARE CAPITAL DOES NOT MATCH NETASSETVALUE, REVISIONOFRESTRICTIONSRELATEDTOTHE ISSUE OF BONDS BY BUSINESS ENTITIES”. 2009. Available online. In: http://ivo.garant.ru/\#/document/12171965/paragraph/555:0. Consultation date: 12/08/2020.

FEDERAL LAW No. 39-FZ "On the Securities Market". 1996. Available online. In: https://cbr.ru/content/document/file/36165/39-fz.pdf. Consultation date: 12/08/2020.

FEDERAL LAW NO. 99-FZ “ON AMENDMENTS TO CHAPTER 4 OF PART ONE OF THE CIVIL CODE OF THE RUSSIAN FEDERATION AND ON THE INVALIDATION OF CERTAIN PROVISIONS OF LEGISLATIVE ACTS OF THE RUSSIAN FEDERATION". 2014. Available online. In: https://www.garant.ru/products/ipo/prime/doc/70548990/. Consultation date: 12/08/2020. 
FILIPPOVA, Sofia. 2012. "On the functions of the registered capital in the context of assessing changes in legislation on business entities" In: Entrepreneurial Law. No. 1, pp. 19-22.

FILIPPOVA, Sofia. 2018. "On the issue of the concept, composition, and structure of the registered capital of a business entity" In: Economy and Law. No. 11, pp. 35-52.

GALKOVA, Ekaterina. 2015. "Correlation between the principle of preservation of the joint-stock company capital and the issuer's responsibility for the securities prospectus” In: Law. No. 11, pp. 114-131.

GLUSHETSKIY, Andrey. 2020. "The registered capital of a business company: an economic analysis of corporate law regulations" In: Bulletin of Civil Law. No. 2, pp. 217-278.

GOLUBTSOV, Valery. 2016. "The Principle of Good Faith as an Element of the Legal Mechanism for Stimulating the Debtor to Proper Execution of Obligations and Guaranteeing Creditors' Interests: Analysis of Judicial and Arbitration Practice” In: Perm University Herald. Juridical Sciences. No. 2(32), pp. 175-184. Available online. In: http://www.jurvestnik.psu. $\mathrm{ru} /$ images/2016-2/2016-2-6-eng.pdf. Consultation date: 11/11/2020.

GOLUBTSOV, Valery. 2018. "Reform of the Law of Obligations: Theoretical and Practical Effect of the Changes Introduced" In: Perm University Herald. Juridical Sciences. No. 3(41), pp. 396-419. Available online. In: http:// www.jurvestnik.psu.ru/images/2018-3/2018-3-3-eng.pdf. Consultation date: $11 / 11 / 2020$.

GUTNIKOV, Oleg. 2015. "Exclusion of a participant in a legal entity: a measure of responsibility and a method of protecting corporate rights" In: Bulletin of Economic Justice of the Russian Federation. No. 2, pp. 49-64.

HANSMANN, Henry; KRAAKMAN, Reinier. 2004. What is Corporate Law? Available online. In: https://ssrn.com/abstract=568623. Consultation date: 12/09/2020.

HUNTER, Dan. 2008. "Teaching and Using Analogy in Law" In: Journal of the Association of Legal Writing Directors. No. 2, pp. 151-168. Available online. In: https://papers.ssrn.com/sol3/papers.cfm?abstract_ id=1089669. Consultation date: 11/11/2020.

JUTHE, André. 2005. "Argument by analogy” In: Argumentation. Vol. 19, No. 1, pp. 1-27.

KLINOVA, Elena. 2007. Civil Law Transactions When Placing Equity Securities. Kazan, Russia. 
KOZLOVA, Natalia; FILIPPOVA, Sofia. 2012. "Legal consequences of nonpayment of the registered capital of a business company: theory and practice" In: The Moscow University Herald. Series 11. Law. No. 3, pp. 72-82.

KURBATOV, Aleksey. 2018. "Resolution of Conflicts with Provisions of the Civil Code of the Russian Federation: The Old and New Problems" In: Journal of Russian Law. No. 10, pp. 36-44.

KUZNETSOV, Viktor. 2011. "On the Freedom of Will when Forming Authorized Capital of a Joint-Stock Company: Based Upon the Materials of Ruling No. 206-O-O of the Constitutional Court of the Russian Federation of February 24, 2011" In: Civilist. No. 4, pp. 47-50.

KYRITSIS, Dimitrios. 2018. Interpreting Legislative Intent. Available online. In: https://papers.ssrn.com/sol3/papers.cfm?abstract_id=3243732. Consultation date: 12/09/2020.

LAPTEV, Vasily. 2017. "Corporate property as a juridical technique in corporal law" In: Journal of Business and Corporate Law. No. 2, pp. 62-68.

LOMAKIN, Dmitry. 2020. Commercial Corporations as Subjects of Corporate Legal Relations: Tutorial. Statute. Moscow, Russia.

MACAGNO, Fabrizio; WALTON, Douglas. 2009. "Argument from Analogy in Law, the Classical Tradition, and Recent Theories" In: Philosophy and Rhetoric. Vol. 42, No. 2, pp. 154-182.

MELNIKOVA, Tatiana. 2016. "The function of contributions to the property of economic partnerships or companies" In: Legal World. No. 9, pp. 7-29.

MIKRYUKOV, Viktor. 2020. "Gaps and Analogies in the Legal Definition of the Lease Facility” In: Journal of Politics and Law. Vol. 13, No. 2, pp. 82-93.

PETROVSKY, Nikolay. 2009. "Analogy method in jurisprudence” In: Modern Law. No. 5. Available online. In: https://www.sovremennoepravo.ru/m/ articles/view/\%Do\%9C\%Do\%B5\%D1\%82\%Do\%BE\%Do\%B4-\%Do \%Bo\%Do\%BD\%Do\%Bo\%Do\%BB\%Do\%BE\%Do\%B3\%Do\%B8\%Do \%B8-\%Do\%B2-\%D1\%8E\%D1\%80\%Do\%B8\%D1\%81\%Do\%BF\%D1\% 80\%D1\%83\%Do\%B4\%Do\%B5\%Do\%BD\%D1\%86\%Do\%B8\%Do\%B8. Consultation date: 11/11/2020.

PORTUESE, Aurelien; GOUGH, Orla; TANEGA, Joseph. 2013. "The Principle of Legal Certainty as a Principle of Economic Efficiency" In: European Journal of Legal Studies. Available online. In: https://papers.ssrn.com/ sol3/papers.cfm?abstract_id=2332016. Consultation date: 11/11/2020. 
POVAROV, Yury. 2010. "Guarantee function of the registered capital: new in joint-stock legislation" In: Law and Economics. No. 7, pp. 20-24.

RUBEKO, Georgiy. 2016. "The registered capital of business entities: some problems of legal regulation" In: Lawyer. No. 10, pp. 28-32.

SAYAPINA, Irina. 2005. "Functions and structure of the registered capital of a limited liability company” In: Law and Politics. No. 6, pp. 138-151.

SCHAUER, Frederick; SPELLMAN, Barbara. 2017. "Analogy, Expertise, and Experience” In: University of Chicago Law Review. Vol. 84, No. 1, pp. 101-120.

SUKHANOV, Yevgeny. 2012. "The registered capital of an economic society in modern corporate law" In: Bulletin of Civil Law. No. 2, pp. 4-35.

SUSLOVA, Svetlana. 2020. "Innominate Phenomena in Civil Law" In: Perm University Herald. Juridical Sciences. No. 2(48), pp. 322-347.

TARASENKO, Yury. 2005. "On the nature of the contribution of property to the registered capital when establishing a joint-stock company" In: News of Higher Educational Institutions. Jurisprudence. No. 3, pp. 21-29.

TELYUKINA, Marina. 2001. "Application of offset of similar counterclaims in certain types of obligations" In: Law and Economics. No. 6, pp. 32-38.

THE ARBITRATION COURT OF THE EAST SIBERIAN DISTRICT. 2019. Resolution. Case No. A78-17696/2017. Available online. In: https:// sudact.ru/arbitral/doc/sQu9FsatDPlC/.Consultation date: 12/08/2020.

THE ARBITRATION COURT OF THE FAR EASTERN DISTRICT. 2017. Resolution. Case No. Ao4-3521/2016. Available online. In: https://ogrn. site/arbitration/8805007-a0435212016/23716643/. Consultation date: 12/08/2020.

THE ARBITRATION COURT OF THE FAR EASTERN FEDERAL DISTRICT. 2017. Resolution. Case No. A59-1172/2016. Available online. In: https:// ogrn.site/arbitration/8740301-a5911722016/23991998/. Consultation date: $12 / 08 / 2020$.

THE ARBITRATION COURT OF THE NORTH-WESTERN DISTRICT. 2017. Resolution. Case No. A56-39738/2015. Available online. In: https://sudact.ru/arbitral/doc/92lCsmPTAuZq/. Consultation date: 12/08/2020.

THE ARBITRATION COURT OF THE NORTH-WESTERN DISTRICT. 2018. Resolution. Case No. A66-10750/2015. Available online. In: 
https://sudact.ru/arbitral/doc/xWSQf1K3rGLP/. Consultation date: 12/08/2020.

THE ARBITRATION COURT OF THE URAL DISTRICT. 2019. Resolution. Case No. A60-39078/2018. Available online. In: https://sudact.ru/ arbitral/doc/olGzf2oPPwN4/. Consultation date: 12/08/2020.

THE ARBITRATION COURT OF THE VOLGA DISTRICT. 2016. Resolution. Case No. A57-27205/2015. Available online. In: https://sudact.ru/ arbitral/doc/UQdwqKmAfGoP/. Consultation date: 12/08/2020.

THE ARBITRATION COURT OF THE VOLGA DISTRICT. 2017. Resolution. Case No. Ao6-4712/2016. Available online. In: https:// ogrn.site/arbitration/8932628-12ap106892016_ao647122016_ fo6173902016/23894951/. Consultation date: 12/08/2020.

THE ARBITRATION COURT OF THE VOLGA DISTRICT. 2019. Resolution. Case No. A57-12783/2018. Available online. In: https://sudact.ru/ arbitral/doc/2i8aBYyjzRJo/. Consultation date: 12/08/2020.

THE ARBITRATION COURT OF THE VOLGA DISTRICT. 2020. Resolution. Case No. A12-26686/2019. Available online. In: https://sudact.ru/ arbitral/doc/tEgCyLWxIXHl/. Consultation date: 12/08/2020.

THE ARBITRATION COURT OF THE VOLGA-VYATKA DISTRICT. 2014. Resolution. Case No. A43-2058/2011. Available online. In: https:// sudact.ru/arbitral/doc/6jEyAU6wixrv/. Consultation date: 12/08/2020.

THE ARBITRATION COURT OF THE VOLGA-VYATKA REGION. 2016. Resolution. Case No. A29-4606/2015. Available online. In: https:// sudact.ru/arbitral/doc/RpRGVgavJL56/. Consultation date: 12/08/2020.

THE CIVIL CODE OF THE RUSSIAN FEDERATION. 1994. Available online. In: http://www.consultant.ru/document/cons_doc_LAW_5142/. Consultation date: 12/08/2020.

THE CONSTITUTIONAL COURT OF THE RUSSIAN FEDERATION. 2018. Definition No. 2615-O. Available online. In: https://legalacts.ru/ sud/opredelenie-konstitutsionnogo-suda-rf-ot-25102018-n-2615-o/. Consultation date: 12/08/2020.

THE FEDERAL ARBITRATION COURT OF THE CENTRAL DISTRICT. 2008. Resolution. Case No. A68-5851/07-168/16. Available online. In: https:// resheniya-sudov.ru/2008/148388/. Consultation date: 12/08/2020. 
THE FEDERAL ARBITRATION COURT OF THE CENTRAL DISTRICT. 2009. Resolution. Case No. A54-1591/2008C9. Available online. In: http:// sudrf.kodeks.ru/rospravo/document/770515403. Consultation date: 12/08/2020.

THE FEDERAL ARBITRATION COURT OF THE EAST SIBERIAN DISTRICT. 2008. Resolution. Case No. A19-4509/05-53-6-4. Available online. In: http://sudrf.kodeks.ru/rospravo/document/875452484. Consultation date: $12 / 08 / 2020$.

THE FEDERAL ARBITRATION COURT OF THE NORTH CAUCASIAN DISTRICT. 2009. Resolution. Case No. A32-11917/2007-55/2742008-16/37. Available online. In: http://sudrf.kodeks.ru/rospravo/ document/780833814. Consultation date: 12/08/2020.

THE FEDERAL ARBITRATION COURT OF THE URAL DISTRICT. 2009. Resolution. Case No. A50-14459/2008-G14. Available online. In: https://kad.arbitr.ru/Document/Pdf/7293ea58-8eae-4e92-92af29be6cda34ed/b222dcfo-8d61-4453-8130-1da4a3d7fc33/A50-144592008_20090721_Reshenija_i_postanovlenija.pdf?isAddStamp=True. Consultation date: $12 / 08 / 2020$.

THE FEDERAL ARBITRATION COURT OF THE VOLGA DISTRICT. 2010. Resolution. Case No. A57-22863/2009. Available online. In: http:// sudrf.kodeks.ru/rospravo/document/882663700. Consultation date: 12/08/2020.

THE FEDERAL ARBITRATION COURT OF THE VOLGA-VYATKA REGION. 2008. Resolution. Case No. A39-245/2007-9/14. Available online. In: http://sudrf.kodeks.ru/rospravo/document/875439395. Consultation date: $12 / 08 / 2020$.

THE FEDERALARBITRATION COURTOFTHEWEST SIBERIAN DISTRICT. 2008. Resolution. Case No. A03-3150/07-37. Available online. In: http://sudrf.kodeks.ru/rospravo/document/875502348. Consultation date: 12/08/2020.

THE MINISTRY OF ECONOMIC DEVELOPMENT OF RUSSIA. 2018. Letter No. OG-D22-12808. Available online. In: http://www.consultant.ru/cons/cgi/online. cgi req $=$ doc\&base $=$ QUEST $\& n=182494 \# 01097708306431413$. Consultation date: 12/08/2020.

THE PRESIDIUM OF THE SUPREME ARBITRATION COURT OF THE RUSSIAN FEDERATION. 2013. Resolution. Case No. A42-6169/2011. Available online. In: https://sudact.ru/arbitral/doc/qUnb7nMoJHYX/. Consultation date: 12/08/2020. 
THE SUPREME ARBITRATION COURT OF THE RUSSIAN FEDERATION. 2009. Definition. Case No. A07-20700/2008. Available online. In: http://sudrf.kodeks.ru/rospravo/document/885176381. Consultation date: 12/08/2020.

THE SUPREME ARBITRATION COURT OF THE RUSSIAN FEDERATION. 2011. Definition. Case No. A46-2352/2010. Available online. In: http:// sudbiblioteka.ru/as/text7/vasud_big_136821.htm. Consultation date: 12/08/2020.

THE SUPREME ARBITRATION COURT OF THE RUSSIAN FEDERATION. 2011. Definition. Case No. A56-59613/2009. Available online. In: https://kad.arbitr.ru/Document/Pdf/3a18fadc-8oeo-4e23-abc9e9af18d4771a/8e6ae319-2fe7-479c-aao1-23bdc9dc1f3a/A56-596132009_20110118_Opredelenie.pdf?isAddStamp=True. Consultation date: $12 / 08 / 2020$.

THE SUPREME ARBITRATION COURT OF THE RUSSIAN FEDERATION. 2014. Definition. Case No. A76-8250/2009-64-159. Available online. In: https://kodeks-gk.ru/document-4345.html. Consultation date: $12 / 08 / 2020$.

WEI, Shen. 2014. "Fading Registered Capital Rules under the Amended Chinese Company Law: Sweeping Changes in Uncertain Contexts" In: International Company and Commercial Law Review. No. 8, pp. 270282.

WEINREB, Lloyd. 2005. Legal Reason: The Use of Analogy in Legal Argument. Cambridge University Press. New York, USA. Available online. In: https://www.codolc.com/books/Legal_Reason_The_Use_Of_ Analogy_In_Legal_Argument.pdf. Consultation date: 11/11/2020. 
Vol. 39 N $^{\circ} 69$

Esta revista fue editada en formato digital y publicada en julio de 2021, por el Fondo Editorial Serbiluz, Universidad del Zulia. Maracaibo-Venezuela 